\title{
Socrates on Why We Should Inquire
}

\author{
David Ebrey
}

At the end of many of Plato's Socratic dialogues, after Socrates shows his interlocutors that they lack knowledge of what some virtue is, he urges them to search for this knowledge. ${ }^{1}$ It is not difficult to see why Socrates would want to search for this knowledge himself. He seems to think that the Oracle wants him to investigate virtue (Apology 29d-30b, 37e-38a). He also seems to think that virtue is a type of knowledge, in which case the search would seem likely to help him acquire virtue. But Socrates' interlocutors are not on this mission and typically do not think that virtue is a type of knowledge. When Socrates urges them to inquire after convincing them of their ignorance, does he provide them with reasons that they are in a position to appreciate ${ }^{2}$ Does he offer anything more than infectious enthusiasm?

Scholars typically focus on Socrates' reasons for his own investigation. ${ }^{3}$ When they ask why he urges others to seek knowledge, they generally cite the idea that virtue is a type of knowledge. ${ }^{4}$ This is fine as an account of Socrates' motivation, but it is not a reason Socrates could, in general, expect his interlocutors to appreciate. Some scholars, such as Wolfsdorf and Reshotko, suggest that Socrates tries to convince his interlocutors that virtue is knowledge and of other substantive ethical views so that they will be motivated to search for knowledge of what virtue is. ${ }^{5}$ But again this cannot be the full story, since Socrates treats all of his

${ }^{1}$ For a standard list of Socratic dialogues, see Vlastos 1991, 46. I discuss primarily the Laches in this article. My main claims do not require accepting that there is a coherent group of Socratic dialogues, although at various points I assume that there is such a group. I am not committing myself to Socrates' views in these dialogues representing those of the historical Socrates nor to these dialogues being composed earlier in Plato's life.

${ }^{2}$ One might want to put this question in terms of whether Socrates provides his interlocutors with subjective reasons. However, 'subjective reasons' sometimes refers to what someone takes to be reasons, even if they are not in fact good reasons. I am asking whether Socrates, once he convinces his interlocutors of their ignorance, provides them with good reasons that they are in a position to accept. In my title question, I am referring to the inquiry that would happen after one has recognized one's own ignorance. I am not referring to the discussions that lead up to this recognition.

${ }^{3}$ For example, Brickhouse and Smith 1994 do not discuss why Socrates urges his interlocutors to engage in such inquiries. They focus instead on a different question, also worth asking: why does Socrates discuss with people about the right way to live (11)? They answer in terms of Socrates' own motivation (12).

${ }^{4}$ For examples Vlastos 1958, 6, Frede 1992, vii-viii, and Wolfsdorf 2008, 30.

5 Wolfsdorf 2008, 30-31 only says that 'in some cases' Socrates uses the claim that virtue is knowledge to shape his interlocutors desires; however, he does not provide an alternative account of how such desires are shaped. Reshotko 2006, 2-3 discusses how Socrates can convince his interlocu- 
interlocutors as if they should be able to see the importance of this search, even if he has not argued that virtue is knowledge. His interlocutors may have their own reasons to search, such as a desire not to look foolish or a competitive desire to acquire the knowledge they thought they had. ${ }^{6}$ While these may in fact motivate them, if anything does, they are not in and of themselves good reasons to inquire - quite often shame and competitiveness lead us astray. Socrates seems to think that once we recognize our ignorance, we should be able to see good reasons to inquire. My question is what those are.

It might seem easy to explain why Socrates thinks his interlocutors should want to search for knowledge of what virtue is. While some of them have conventional notions of what is good and others reject such notions, each of them, Socrates thinks, wants what is good. And Socrates thinks that it is by virtue that we are good (e.g., Laches 190b, Meno 73c). Thus, it might seem that everyone should want to know what virtue is. However, merely wanting virtue does not obviously provide a reason to seek knowledge of what it is. You do not need to investigate health to be healthy. Perhaps instead of seeking knowledge of what virtue is we should simply follow the advice we get from parents, poets, or some other authority, much as one goes to a doctor to become healthy. Even if you want to be good and Socrates convinces you that you lack knowledge of what it is to be good, why should you consider this ignorance a particularly serious problem?

I argue that in the Laches Socrates provides an answer to this question that is powerful in its simplicity. He thinks that it is of paramount importance to acquire knowledge of what virtue is because this knowledge is needed to determine what we should aim at. Some activity recommended by poets might in fact help us, but without knowledge of what virtue is we cannot tell whether it does so. ${ }^{7}$ This argument starts from simple and apparently obvious premises and reaches a surprising and potentially life-altering conclusion: that the most important thing is for us to learn what virtue is. Leaving this out of our standard account of Socrates distorts our picture of his ethical views and of why he thinks others should be motivated to search for such knowledge. It is also an argument that we should take seriously on its own merits, one that is especially gripping because it does not rely on very substantive theses.

The argument does not claim that being good requires having knowledge or that knowledge is valuable for its own sake. Rather, it claims that you need a particular sort of knowledge to recognize whether you are becoming better. The

tors to search for knowledge. She does not provide any reason why Socrates' interlocutors would be motivated until he convinces them of his ethical views (in particular, the claim that virtue is knowledge).

${ }^{6}$ For a discussion of what Plato thinks, in fact, tends to motivate people and why they frequently resist Socrates' ethical views and injunctions, see Moss 2007.

${ }^{7}$ Brickhouse and Smith 1994, 43, argue that for Socrates knowledge is valuable because it provides us with a reliable guide in one's pursuit of the good life. I am adding the new idea that Socrates uses this feature of knowledge to motivate his interlocutors to search and that this points to a distinctive value of knowledge. 
argument points to an instrumental, not an intrinsic value of knowledge, an instrumental value anyone could appreciate. Working through the argument helps us tease apart different reasons Socrates thinks knowledge is valuable. Distinguishing these helps us avoid an overly simplistic view of his intellectualism.

A terse passage at the end of the Laches presents Socrates' reasoning in a compressed form. First I consider what we can learn from the passage itself. In the next section, I consider what we should draw from earlier in the dialogue to fill out Socrates' reasoning. Once the argument is filled out, I discuss some of its important and interesting features. As we will see, in this passage at the end of the Laches Socrates urges his interlocutors to search for a teacher of virtue. In the final section I situate Socrates' argument within his larger concerns about whether virtue is teachable.

\section{The Hortatory Passage}

Although Socrates clearly views it as a serious problem that we do not know what the virtues are, it is not easy to find passages that explain why it is so serious. This is because in most Socratic dialogues his interlocutors (especially the adults) start out believing that they already know the answer to the relevant 'what is it?' question. Hence, in these dialogues Socrates focuses on testing his interlocutors' claims to knowledge. It is only at the end of the dialogue that Socrates can urge them to seek knowledge, once they are in a position to see that they lack it. At the end of the Laches Socrates goes furthest in articulating this urgency and providing the outline of an argument for thinking that one must search for knowledge of what virtue is. ${ }^{8}$ I focus on the Laches, not because I think it reflects a view that Socrates would accept only in this dialogue, but because I think this is where Socrates articulates his view most clearly. ${ }^{9}$ This is to be expected, given how much of the dialogue is devoted to motivating his interlocutors. The first

${ }^{8}$ The Euthydemus provides a lengthy argument that we should value wisdom and virtue, in the so-called first protreptic (277d-282e). But this is not an argument that Socrates thinks any interlocutor should be able to appreciate; he must secure Clinias' agreement to a number of key premises. For further discussion of this argument, see n13.

${ }^{9}$ The case I make can be read simply as an account of Socrates' argument at the end of the Laches. The considerations I draw from other dialogues are then irrelevant. How does the end of the Laches compare with the ending of other aporetic Socratic dialogues? In most of these, it is not clear that the interlocutors have really accepted that they lack knowledge (Euthyphro, Greater and Lesser Hippias, Ion, Protagoras, and Meno). Sometimes Socrates nevertheless makes a call for inquiry, even if it is not clear that the interlocutor sees the need for it (Protagoras, Meno, Hippias Major). In the Ion they agree that Ion himself has something divine, which makes it unclear whether there is any need for him to acquire knowledge. In the Euthydemus Crito already agrees about the importance of acquiring the relevant knowledge, so the conversation turns to how he should acquire it. In some ways, the most interesting case is the Charmides. Socrates suggests that Charmides investigate whether he has temperance (176a). Charmides ignores this and insists, instead, on spending time with Socrates. Note that this is the opposite of what Socrates suggests in the Laches: that they do not recruit him but rather find a genuine teacher. The end of the Charmides is clearly supposed to show Charmides and Critias' domineering, tyrannical side. By contrast, the Laches shows the right way to respond to one's ignorance. 
half of the dialogue carefully lays out why ordinary concerns about how to raise one's children can only be answered if one can answer, 'what is courage?' Thus, it is not surprising that at the end of the dialogue Socrates emphasizes that they should search for knowledge of this, now that they have come up empty handed. As we will see, in the key passage at the end of the dialogue Socrates returns to several topics that were central earlier: the search for teachers, what to do when you receive conflicting advice, and the role of knowledge in decision making.

The key passage arises after Laches and Nicias return to the opening topic of the dialogue: how to help Lysimachus and Melesias' sons turn out well. Laches and Nicias suggest that Socrates teach the two children and Lysimachus joins in this call, saying that Socrates should 'take an active part with us in helping the young men to become as good as possible' (200d7-8). ${ }^{10}$ Socrates had just been speaking with Nicias, who accepts the Socratic idea that virtue is a type of knowledge (194c-d), but now Socrates is engaged in a wider discussion with all four adults, including Laches who was skeptical that virtue is a type of knowledge (e.g., 195e). With this background in place, we turn to the key passage, which I will call 'the hortatory passage':

Well, it would be a terrible thing, Lysimachus, to be unwilling to join in assisting any man in becoming as good as possible. If in the conversations we have just had I had seemed to be knowing and the other two had not, then it would be right to issue a special invitation to me to perform this task; but, as the matter stands, we were all in the same difficulty. Why then should anybody choose one of us in preference to another? What I think is that he ought to choose none of us. But as things are, see whether the suggestion I am about to make may not be a good one: what I say we ought to do, my friends - since this is just between ourselves - is to join in searching for the best possible teacher, first for ourselves - we really need one - and then for the young men, sparing neither money nor anything else. (200e1-201a6)

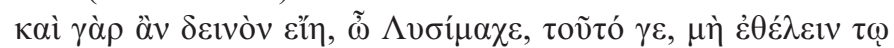

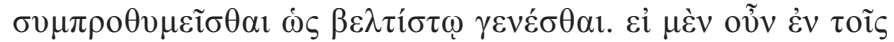

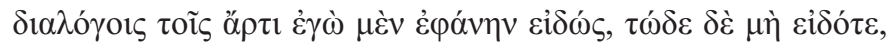

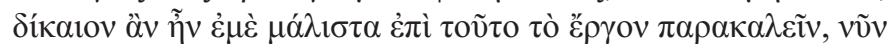

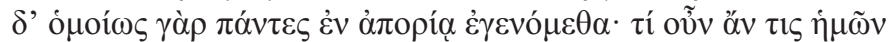

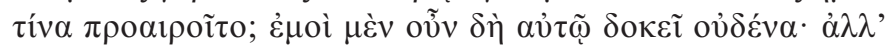

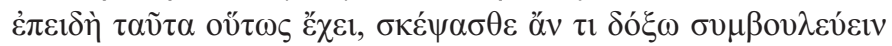

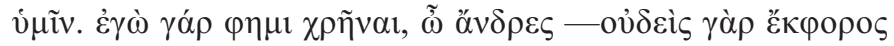



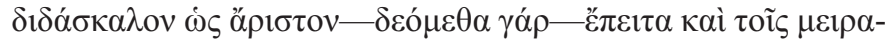

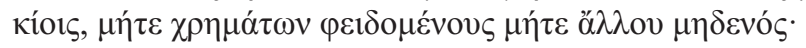

${ }^{10}$ All translations of the Laches revised from Rosamond Kent Sprague's translation in Cooper ed. 1997. 
In what follows, I examine Socrates' claims in this passage and then, in the next section, I draw on what has come earlier in the dialogue to fill in his reasoning, with the ultimate goal of reconstructing Socrates' argument so that the conclusion necessarily follows from premises that his interlocutors would accept. While filling in implicit premises is not always illuminating, in this case it does help us understand Socrates' reasoning.

Socrates says at the beginning of the hortatory passage, "Well, it would be a terrible thing, Lysimachus, to be unwilling to join in assisting any man in becoming as good as possible.' It would be terrible because becoming good is so important. At the end of the passage he says that they should spare nothing to find the best teacher possible. The dialogue starts with Lysimachus and Melesias seeking advice on how their sons can become as good as possible, an endeavor that Laches and Nicias enthusiastically support. Socrates has emphasized earlier that this is the most important subject: 'Or do you [Melesias] and Lysimachus suppose that the subject in question is some small thing and not the greatest of all our questions? The question is really, I suppose, that of whether your sons turn out to be worthwhile persons or the opposite - and the father's whole household will be managed in accordance with the way the sons turn out' (185a3-7; cf. 187d). Everyone in the Laches is agreed on the paramount importance of becoming as good as possible.

Socrates and his interlocutors can easily accept the paramount importance of becoming good because he is not presupposing a substantive conception of what makes someone good. Socrates makes strong, sometimes radical claims about what things are good, but these are not part of the term's basic meaning for him. ${ }^{11}$ They have agreed earlier that they are interested in improving the soul (185d-e), but aside from this restriction, what Socrates is saying in the hortatory passage is compatible with practically anything being good: knowing how to play backgammon, pleasure, freedom, the power to do whatever we feel like, contemplating... We should not confuse the claim here with another idea found in Plato and Aristotle (and that Socrates may independently hold as well), that our highest good involves thinking. ${ }^{12}$ As far as the argument in the hortatory passage is concerned, the use of our intellect might be purely instrumental. If we were to learn, for example, that base pleasures are the highest good, then (as far as this argument goes) we could cease using our intellects and start living the best life, the life of pigs. If the good could not be like this, it is for reasons that have nothing to do with this argument. ${ }^{13}$

${ }^{11}$ I address the connection between good and virtue at the end of this section.

12 In fact, I think that this idea is not found in Plato's Socratic dialogues, but rather is something found in his middle-period dialogues. But that requires a separate argument.

13 Socrates argues that all virtue is a type of knowledge in the Euthydemus, Meno, and Protagoras. According to the arguments in those dialogues, even if the good turns out to be something like pleasure, we still need knowledge to acquire the good, because it is the only guide to the good. These arguments provide us with a different reason to seek knowledge. We find something similar in the Laches. Nicias attributes to Socrates the view that everyone is good with respect to those things of which he is wise (194d). And Socrates' final refutation of Nicias' definition is often taken to be an 
Socrates does not always bring to bear his own beliefs about what is good. For example, in the Protagoras he acknowledges that some people think of things as good insofar as they are pleasurable and bad insofar as they are painful. But he understands that not everyone holds this view: if nothing else, Protagoras is clearly resistant (351c-e). Socrates is able to consider a basic notion of good that abstracts from the particulars of different peoples' beliefs about it. ${ }^{14}$ Given Socrates' profession of ignorance, he has reason to be non-committal. If he claims not to know what the best life involves, he should not silently presuppose substantive claims about it. ${ }^{15}$

Thus, Socrates is operating with this premise in the hortatory passage:

1. Becoming as good as possible is the most important thing to do.

Without relying on substantive claims about what it is to be good, Socrates is confident that we should all try to become good, whatever that turns out to involve. This is uncontroversial, perhaps an analytic or conceptual claim, although Socrates does not seem to have a theory of such claims. ${ }^{16}$ 'Important' in the above premise means valuable given the situation that a person is in, not what is ultimately most valuable. What is ultimately most valuable is being good, not becoming good. But given that someone is not already good, what is most important is to become good, because this is needed to be good. If drinking water is good, then getting a glass might be as important as drinking water (if this is necessary for drinking), but getting a glass is not ultimately as valuable as drinking water.

In addition to this claim about the importance of becoming good, the hortatory passage also says that none of the discussants have the relevant knowledge, which alludes to their inability to say what courage is. The passage comes at the end of the Laches because it is only here that Socrates can expect them to acknowledge that they do not know what courage is. They choose to discuss courage because they want to improve their sons. They decide to focus on courage, in particular, on the grounds that this will be easier and that it is the most relevant part of virtue given the fathers' interest in fighting in armor (190c-

indirect indication (albeit one that the interlocutors do not seem to appreciate) that virtue is a single type of knowledge (see, e.g., Penner 1992). Thus, we should distinguish between three different ethical roles for knowledge: we might need knowledge of what virtue is in order to recognize how to become better, even if virtue is not a type of knowledge; virtue itself might turn out to be a type of knowledge (as Socrates argues in the Euthydemus, Meno, and Protagoras and perhaps Laches), even if the good is something like pleasure; and the good itself might turn out to involve knowledge. In Ebrey 2017 I discuss how this latter idea is defended in the Phaedo.

${ }^{14}$ See also the Lysis (esp. 214b-end).

15 This is complicated by the different ways interpreters understand Socrates' profession of ignorance. Many claim that Socrates allows himself certain types of knowledge (e.g., non-expert knowledge, elenctic knowledge, or knowledge that) while not allowing himself others (expert knowledge, certain knowledge, or knowledge how; see Reeve 1989, Vlastos 1991, and Brickhouse and Smith 1994, respectively). For criticisms of these views, see Wolfsdorf 2004. Even if Socrates does allow himself significant ethical knowledge, he does not simply presuppose it.

${ }^{16}$ For a discussion of how we might think of such claims, see Ebrey 2013, 85-86. 
d), but they are ultimately interested in knowing what virtue is, since this is what someone would need in order to improve a person's soul overall (189e-190c). Since none of them has been shown to know what courage is, and this is taken to be the easier type of knowledge that the generals would be more likely to know, Socrates suggests in the hortatory passage that none of them has been shown to have the knowledge needed to improve the sons. Clearly he thinks they lack the general knowledge of what virtue is, not simply knowledge of courage. Thus, Socrates is relying on this premise in the passage:

5 . We do not know what virtue is.

If Socrates or the other interlocutors had this sort of knowledge, they would be able to give advice about how to improve the sons. I have labeled the premise ' 5 ' because there is a gap, I will argue, between this and the other premise in the passage, a gap that requires three intervening premises to bridge.

For Socrates, there is a very tight connection between good and virtue, which he treats as uncontroversial. This connection can be brought out by translating arête as 'excellence' instead of 'virtue'. In fact, there are good reasons to think that in Attic Greek arête functions as the abstract noun that corresponds to the adjective that means good, 'agathos', so you could also translate it 'goodness'. ${ }^{17}$ Virtue, i.e., excellence or goodness, is that by which we are good. ${ }^{18}$ They are so tightly linked that knowledge of one goes along with knowledge of the other. Thus, Socrates is relying on this premise:

4. Knowing what it is to be good requires knowing what virtue is. ${ }^{19}$

We see Socrates tightly connecting virtue with being good in the hortatory passage: he says that he cannot help the children become as good as possible since he does not know what courage is. He also assumes a tight connection in earlier arguments. For example, he treats it as obvious that virtue is the thing that, when added to the soul, makes it better $(189 \mathrm{e}-190 \mathrm{c})$. He never suggests that someone might have knowledge of one without knowledge of the other.

One might try to use this connection between virtue and being good to argue that Socrates builds strong commitments into his notion of the good. If Socrates were to build strong commitments into his notion of virtue, then, given the conection between good and virtue, he would have strong commitments built into

17 Dover 1974, 67 suggests in passing that $\alpha \rho \varepsilon \tau \eta$ simply is the abstract noun corresponding to $\dot{\alpha} \gamma \alpha \theta$ ó $\varsigma$, a very reasonable suggestion for fourth century Greek ( $\dot{\alpha} \gamma \alpha \theta \dot{\alpha} \tau \eta \zeta$ and $\alpha \rho \varepsilon \tau \eta \varphi o ́ \rho o \varsigma$ are later developments). Hence, Griffith translates $\dot{\alpha} \rho \varepsilon \tau \eta$ as 'goodness' in his translation of the Protagoras (Schofield 2010). See Adkins 1960 for an account of how this connection was built into Greek

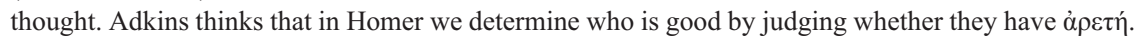
At the end of Republic i we have a different picture: $\dot{\alpha} \rho \varepsilon \tau \eta ்$ is what leads to good things. For my purposes, we need not decide on the precise sort of connection between $\dot{\alpha} \gamma \alpha \theta$ ó $\varsigma$ and $\dot{\alpha} \rho \varepsilon \tau \dot{n}$ as long as knowledge of what $\dot{\alpha} \gamma \alpha \theta$ ó $\zeta$ is requires knowledge of what $\dot{\alpha} \rho \varepsilon \tau \eta \dot{~ i s . ~}$

18 This is not to say that virtue is a mere instrument by which we are good. Instead, I take it Socrates thinks of virtue as the source of our being good, just as wisdom brings about being wise and courage being courageous. But again, the precise relation does not matter for our purposes.

19 This is meant as strict logical requirement. I do not mean to presume that these are distinct branches of knowledge. They may turn out to be the very same knowledge. 
his notion of the good. However, Socrates also uses 'virtue' in a noncommittal way, as something like 'whatever makes us good' (Laches 190b), and that is the use relevant here at the end of the Laches. He uses it in a noncommittal way when he asks his interlocutors a 'what is it?' questions about some virtue. When he does this, he is asking them to provide a substantive account; he does not presuppose one of his own.

\section{Bridging the Gap in Socrates' Argument}

We have seen the outline of Socrates' argument in the hortatory passage: the most important thing is to become as good as possible, yet we do not know what virtue is; so, we ought to find a teacher. To fill in this argument, we need to answer a number of questions. One is what Socrates wants from a teacher. There are different ways in which someone could be considered a teacher of virtue. Does Socrates want someone who will teach them what courage is? Or does he want not just this, but also to acquire knowledge of how to add courage to the soul? Or does he want a teacher simply to make them and the young men better, but not necessarily to provide any knowledge, just as a physical trainer or doctor can make us healthier without providing knowledge of health?

To answer these questions we need to know how the premises in the hortatory passage are related to each other: why think that lacking knowledge of what virtue is has anything to do with the paramount importance of being good? Is Socrates presupposing a strong conception of what it is to be good, one that he has not argued for? ${ }^{20}$ It would not even be enough for Socrates to presuppose that we would be made better by knowledge of what virtue is. For the argument to work, he would need the stronger claim that this knowledge is the only or the best way to become as good as possible (or some sort of necessary condition for this). Otherwise, the lack of knowledge might be irrelevant, since another method might be more effective.

Happily, we need not interpret Socrates as assuming in the hortatory passage that knowledge is necessary for becoming good or even the best way to do so. Perhaps a better method is to do whatever parents, priests, or poets suggest, or whatever you feel like. The problem is that we cannot determine whether these things help us become better or not, precisely because we do not know what virtue is. So while learning might not be the most effective way to become better, we have no way of determining this. Knowing what-virtue-is is the only way to recognize what to aim at. Parents, priests, and poets certainly try to provide guidance. The problem with their advice is that it sometimes conflicts and, even without a conflict, we need some way to recognize whether it should be trusted.

${ }^{20}$ In Socrates' refutation of Nicias, Socrates suggests that anyone who had knowledge of all good and evil would not depart from virtue in any way (199d). Thus, Socrates assumes here that knowledge of good and evil is the same as virtue, or at least that they go together. Socrates may well be assuming this because he is talking to Nicias, who earlier praised the idea that these go together (194c-d). But throughout the dialogue Laches is suspicious of the idea and Lysimachus and Melesias are silent on the topic, so Socrates cannot simply presuppose the idea when talking to all of them. 
According to this interpretation, Socrates thinks they need a teacher, at least at first, to teach them what virtue is.

This interpretation fits naturally with how Socrates motivates the search for what courage is in the first half of the Laches. The dialogue begins with Lysimachus and Melesias uncertain about how to raise their sons. They bring in two generals who, it turns out, have contrary views about the value of fighting in armor. Lysimachus and Melesias need some way to arbitrate the conflicting advice. Socrates' claim is that they should determine what to do on the basis of knowledge (184e). He leaves open that one of the generals might have knowledge, but first they need to determine whether he does (184e-185a). Socrates thinks they should not simply act on the advice of someone who is in fact an expert; they need to recognize that this person is an expert. Socrates says that you can identify an expert by determining if someone has produced good results or had good teachers (185d-186a). When it comes to something like gymnastics, we are clear about what constitutes improvement, so we can tell who is an expert by seeing whether they improve someone. But in this case Socrates does not know what the good result is and so cannot say who has the right advice (186d-e). Socrates argues that they are looking for an expert with knowledge of how to add virtue to the soul, since this is the sort of improvement they are looking for in their sons. He argues that in order to be such an expert one must know what virtue is $(189 \mathrm{e}-190 \mathrm{c})$.

What sort of knowledge do they need in order to recognize an expert? As I just mentioned, in the Laches Socrates distinguishes knowledge of what virtue is from knowledge of how to instill virtue, treating the former as a prerequisite for the latter. On the face of it these types of knowledge seem distinct: knowing what virtue is seems like it would involve much less than knowing how to inculcate it in souls, just as there is a big difference between simply knowing what health is and having a doctor's knowledge. These two types of knowledge correspond to two groups of people that Socrates says need to know what sight and hearing are: both doctors who heal the eyes and ears, and those who want to be worthy counselors ( $\sigma u ́ \mu \beta o v \lambda o \imath)$ concerning the eyes and the ears (190a-b). You should not counsel someone about how to improve his or her sight if you do not know what sight is. But if you do know what it is, you could recommend a good doctor, without being one yourself. ${ }^{21}$ They only need knowledge of what virtue is to recognize an expert. ${ }^{22}$ In revealing that neither Laches nor Nicias knows what

${ }^{21}$ For a mostly complementary discussion, see Hagen 2013 section 3.2, esp. p. 67. We agree that someone does not need to be an expert in order to recognize an expert. Hagen argues that elenchus is needed to identify an expert, whereas I am arguing that one would need knowledge of what would count as improvement. My account suggests a different way to resolve the puzzle he develops and addresses in chapter 3 of how much we should defer to moral experts. I am arguing that we cannot defer to them on the question of what counts as being a good person although we can defer to them on the technical question of how to become such a person.

${ }^{22}$ Similarly, in the Protagoras Socrates says that Protagoras is a merchant of teaching and that before Hippocrates purchases his teachings he should know whether they are helpful or harmful $(313 \mathrm{c}-314 \mathrm{c})$. We need to know what these teachings are that we are taking into our soul so we can 
courage is, Socrates shows that they both are not experts and are not able to identify them.

Some commentators have attributed to Socrates the view that in order to know what courage is, you must be an expert who knows how to make someone courageous. ${ }^{23}$ Perhaps this is what Socrates thinks, but even if so, it is not something he can simply assume. As we have seen, in the Laches Socrates acknowledges that in general it is one thing to recognize a good product and quite another thing to produce it oneself. And it is plausible that this would apply to the case of courage: that instilling courage requires a quite complex method. Socrates would need to argue that these two types of knowledge collapse into one another, especially given that he has explicitly distinguished them earlier in the dialogue. Since he does not argue that these two types of knowledge turn out to be the same, we should continue to treat them as separate in the hortatory passage. The first step is to find a teacher who will teach them what virtue is.

This interpretation explains why Socrates says in the hortatory passage that if he had turned out to be knowing he could play a special role in educating the Melesias and Lysimachus' sons. If Socrates learned knew what courage is, he might not have technical expertise of how to instill it in people's souls, but he could at least identify what counts as the result they are looking for, and hence could offer useful suggestions. This is also why Socrates suggests in the hortatory passage that they need a teacher first for themselves, then for their children. It is not that they value themselves over their children. Rather, since they are the ones making the decisions about the children's lives, they need knowledge of what virtue is to make sure that the children are being improved.

It might seem that all one needs is a true belief, not knowledge, about what is good. But this would not help, unless one could recognize whether one's belief is true. After all, of the two generals, one has a true belief - either training to fight in armor will help the children become as good as possible, or it will not—but this does not help Lysimachus and Melesias, nor should it console the generals themselves. If you cannot recognize whether your belief about an important topic is correct, you should find some way to determine whether it is. The possibility that you might be right, unbeknownst to you, is no reason to stop investigating. Thus, while true beliefs can guide as well as knowledge (Meno 97a ff.), this is not relevant to this argument, since it is about recognizing whether one is doing better. ${ }^{24}$

know whether they are helpful. Here Socrates seems to allow that one could be a knowledgeable consumer, who has knowledge of the teachings, without necessarily knowing the teacher's methods. By contrast, in the Charmides (171b-c) Socrates does not suggest that we can recognize experts by evaluating their products. Instead, in the Charmides he suggests that one must be a relevant expert in order to recognize an expert in a given area.

${ }^{23}$ E.g., Reshotko 2006, 169, and Nehamas 1987, 297-298.

${ }^{24}$ Might there be some epistemic state stronger than mere true belief and weaker than knowledge, which would allow us to recognize whether we are doing the right thing? Socrates never discusses any such state and it is not clear how it would work. It would need to provide rational confidence about how to live. Perhaps it is possible, without knowledge, to have this sort of rational 
In sum, Socrates thinks we need knowledge of what we are aiming at in order to recognize it. ${ }^{25}$ Thus, Socrates is relying on a premise that connects knowledge to an ability to recognize:

3. In order to be able to recognize whether we are good, we need to know what it is to be good.

We also need a premise about the importance of meeting one's goals and recognizing that one has done so:

2. However important it is that we accomplish something, it is equally important to do what is needed to accomplish this and to be able to recognize whether we have accomplished this.

One should do what is needed to reach one's goals. But, from one's own perspective, it is also crucial to recognize whether one's goals are accomplished. This is not only important for determining if one has succeeded, but also for determining if an expert (or something else) is able to produce the result one is looking for. If it is important that I recover from an illness, I do not need to be able to tell at every moment that I am recovering, but it is important that I be able to recognize what recovery would consist in-what it would be to be healthy. As we have seen, Socrates does not simply want to follow the generals' advice, if it happens to be right; he wants to be able to recognize that the general is an expert. Notice that these last two premises, like the others, are claims that Socrates can reasonably expect his interlocutors to accept.

We can now fill out Socrates' argument in the hortatory passage:

1. Becoming as good as possible is the most important thing to do.

2. However important it is that we accomplish something, it is equally important to do what is needed to accomplish this and to be able to recognize whether we have accomplished this.

3. In order to be able to recognize whether we are good, we must know what it is to be good.

4. Knowing what it is to be good requires knowing what virtue is.

5. We do not know what virtue is.

Conclusion: The most important thing for us to do is to learn (i.e., acquire knowledge of) what virtue is. ${ }^{26}$

confidence about certain topics, but it is hard to see how we could have this confidence about the best way to live. We certainly can have beliefs about the best way to live, beliefs that are based on reasons and that guide our actions. But such beliefs should be open to revision, so it makes sense to continue searching for knowledge in order genuinely to recognize what to do. We can see why Socrates does not mention anything weaker than knowledge. As for Socrates' own confidence about how to live, I address this in the next section and in the conclusion.

${ }^{25}$ For a discussion of the claim that knowledge is needed for recognition in the Meno, see Ebrey 2013.

26 This argument is similar to a simple outline of an argument in Vasiliou 2008, 137 and to a more developed argument in Rudebusch 2009, 22-28. Unlike me, neither of them is trying to present an argument that Socrates thinks his interlocutors should accept. Vasiliou claims that for Socrates knowledge of definitions determines what is needed for our actions to be good, whereas I do not think that Socrates is focusing on actions here; otherwise, his argument is similar to premises 1 and 5 above, with the intermediate premises assumed. An even closer parallel is found in Rudebusch 2009, 
This argument provides one reason that Socrates himself wants to search for knowledge of what virtue is. But it is also an argument Socrates could reasonably expect to motivate anyone who accepts his or her own ignorance about virtue; that is, anyone who accepts the fifth premise. The conclusion captures the sense one gets throughout the Socratic dialogues that Socrates thinks we should see it as incredibly important to acquire knowledge either of what one of the virtues is or of the whole of virtue.

I have argued that Socrates in the hortatory passage hopes to find a teacher who will help him acquire knowledge of what virtue is, not to acquire expert knowledge nor simple improvement of his soul. Socrates has given no reason to think that they need to acquire technical knowledge of how to acquire virtue. For all he has said, they can defer to an expert who has technical knowledge of this. At the same time, it is not sufficient to simply be improved; they need some way to recognize the good result they are looking for, and so they need knowledge of what virtue is. Upon discovering that they lack knowledge of what virtue is, Socrates is saying that they should acquire this knowledge. On this reading, Socrates has no principled reason to insist on a teacher, per se, rather than on trying to acquire this knowledge on their own. Earlier in the Laches Socrates has said that one can become an expert without a teacher (186a-b), so clearly he does not think that teachers are strictly necessary. Similarly, at the end of the Euthyde$m u s$, Crito balks at Socrates' suggestion that they find a teacher. In response, Socrates says that Crito should instead pursue the topic on his own, leaving aside the self-proclaimed practitioners (307a-c).

\section{Key Features of the Argument}

According to this argument three things are of greatest importance to us: recognizing what it is to be good, recognizing what virtue is, and becoming as good as possible. Yet none of these is our highest good. In our current situation these are as important as our highest good (whatever that turns out to be) because they are needed to identify this good and reach it. As a result, the argument does not apply regardless of circumstances. If someone already has this knowledge or were to gain it, the argument would not apply to him or her. ${ }^{27}$ This explains how Socrates can be confident that we should really do something, search for knowledge, despite denying that he knows what we should do. He is not relying on substantive knowledge about the good; instead, he relies on much weaker premises about what is important to do when one does not know what the highest good is.

22-28, esp. 25. Focusing on the Apology, Rudebusch discusses how recognizing one's ignorance of ethical matters can provide reasons to search for knowledge. Unlike the argument I presented above, Rudebusch structures his argument around our obligation to avoid harm: we can do harm because we lack such knowledge and so it would be negligent for us not to try to acquire this knowledge. By contrast, Socrates' argument in the Laches does not suggest that our motivation is to avoid harm. For further discussion of his argument, see n32, below.

${ }^{27}$ Nehamas 1998, 9 says that Socrates' goal is universalist and, in some sense, that is surely true. But his goal is grounded in the actual circumstances in which he finds himself, so in another sense it is not universalist at all. 
Our ignorance rears its head in two ways in the argument. First, we do not know what we should be doing and second, because of this, we do not know how to proceed other than by figuring out what to do. To put it slightly differently, our ignorance creates a question: how can we become good? And it constrains how we can find an answer: only by acquiring knowledge can we recognize the correct answer. The recent scholarly literature on Socratic ignorance, following Vlastos' lead, has not focused on Socratic ignorance as a source of motivation. It focuses on Socratic ignorance as a puzzle in its own right (Vlastos 1958 and 1985 ) and as the backdrop for methodological questions (Vlastos 1983). Once this puzzle has been addressed and the methodology explained, most discussions turn to an independent investigation of Socrates' ethical views. ${ }^{28} \mathrm{I}$ am claiming that one of his views (the importance of inquiry into the virtues) is motivated in part by ignorance: anyone who recognizes that he or she is ignorant of virtue, including Socrates himself, should seek out this knowledge. Socrates wants us to be aware of our ignorance about virtue because this makes clear how we should act now, given our ignorance. If we treat Socrates' ignorance as a puzzle that has already been dealt with, we miss this motivation.

Some scholars, drawing primarily on the Apology, have claimed that Socrates thinks that we cannot acquire knowledge of what virtue is. ${ }^{29}$ If he thought we could not acquire such knowledge, it is hard to see how he could think that this inquiry is the most important thing for us to do. While Socrates might be providing his interlocutors with reasons to inquire, he could not take these to be good reasons. It would take us too far from our central concerns to resolve this debate about how to read the Apology. I do not think he eliminates all possibility of acquiring ethical knowledge in the Apology, but even if he does, he certainly is open to the possibility in the Laches. ${ }^{30}$ My primary goal is to lay out Socrates' view in the Laches of why his interlocutors should inquire. ${ }^{31}$

${ }^{28}$ For example, see Brickhouse and Smith 1994 and Irwin 1995. Of course, not all scholarship is structured this way, but these examples are indicative of how many scholars view these issues.

${ }^{29}$ Brickhouse and Smith 1994, 42 take a more moderate version of this sort of line: they think that there is a type of knowledge that Socrates does not have and likely could never acquire using (what they claim is) his only way of philosophizing, the elenchus. Foster 2006 and 2007 take a stronger line, that Socrates thinks it is impossible for anyone to acquire any sort of ethical knowledge. Benson 2000 argues against all such interpretations (see chapter 2, esp. p. 17 and, on the Laches, pp. 25-26).

${ }^{30}$ Forster 2006, 21 claims that the teacher at the end of the Laches is supposed to be Apollo, since no human has such knowledge. I do not find this a very plausible idea, but even if it were true, Apollo would be a teacher and so would be able to provide knowledge to Socrates, Laches, Lysimachus, etc.

${ }^{31}$ If you think that in the Apology Socrates denies all possibility of acquiring ethical knowledge, you might want to limit the scope of this argument to only the Laches: perhaps it does not explain, across dialogues, why Socrates thinks that everyone should inquire if aware of his or her own ignorance. But given that in the Republic Socrates clearly thinks we can acquire ethical knowledge, the Laches could be pointing in the direction that Plato is heading, on standard chronologies. One would then need to decide whether or not in other Socratic dialogues Socrates is open to the possibility of acquiring genuine ethical knowledge. If, like me, you think that Socrates allows for the possibility of 
Even granted that Socrates allows that we can acquire knowledge of what virtue is, he certainly would recognize that we are unlikely to succeed in acquiring this. If we are unlikely to succeed, are there good reasons to try? Yes. An important part of why we should inquire is that we do not know what we should be doing and so we also do not know of any competing second-best activity to engage in. Of course, circumstances may force us to act in other ways: to take care of children, to go to war, to address the assembly. Socrates' argument need not lead to action paralysis or withdrawal from worldly affairs. Sometimes we must act without recognizing the best way to act. When this happens, what one should do, both intuitively and according to Socrates in the Crito, is act in accordance with the argument that seems best (46b). But nonetheless, overall the most important thing for us to do is to inquire into what virtue is. We do not know what we should do other than to search for knowledge of what we should do. ${ }^{32}$

\section{Are there teachers of virtue?}

I have argued that at the end of the Laches Socrates is urging his interlocutors to search for someone to teach them what virtue is, not (at least at first) a teacher who will directly improve their souls. Is this injunction compatible with the concerns about the teachability of virtue that Socrates raises in the Protagoras and Meno? Such concerns may be alluded to earlier in the Laches, when Socrates mentions that he has been unable to find a teacher, despite longing for one from his youth (186b-c). If the conclusion of Socrates' argument, as I have interpreted it, is incompatible with Socrates' concerns about the teachability of virtue, this would provide reason to reevaluate my interpretation. However, as we will see, my account is compatible with Socrates' concerns; seeing why will deepen our understanding of Socrates' argument in the hortatory passage as well as our understanding of Socrates' concerns about the teachability of virtue.

Socrates suggests at the end of both the Protagoras (361c-d) and Meno (100b) that he and his interlocutors should learn what virtue is and use this to inquire into whether it is teachable. Thus, Socrates thinks, in principle at least, that someone could learn what virtue is, and yet it turn out that virtue itself cannot be taught. Earlier in these dialogues he makes clear how this could happen: they might learn that virtue is something that simply comes to people by nature, or as an unprompted gift from the gods. Someone could then teach you what virtue is, but learning this would not help you acquire virtue, just as I could tell you what it is to naturally have red hair without this helping you acquire such hair. Yet if virtue is teachable, then it is possible for someone to help you acquire virtue. The debate about whether virtue is teachable depends, to a large degree, on whether

acquiring ethical knowledge in the Apology, you avoid this host of issues.

32 Rudebusch 2009, 25 argues that even if we are unlikely to acquire such knowledge, we should pursue it, since to do otherwise is negligent. Note that this could only be negligent given the great importance of this topic and given that we do not know of any other, similarly pressing issues. It is not negligent to fail to pursue something if it is unlikely to succeed and if we know of some other matter that we could succeed at instead that is at least as important. 
the acquisition of virtue is within our control. ${ }^{33}$ Hence, using the distinction we drew earlier, it might be possible to find one sort of teacher of virtue-someone who can teach you what it is - without finding the other sort- someone who can help you acquire virtue.

Thus, even if virtue is not teachable, we could still do what Socrates suggests at the end of the argument: search for knowledge of what virtue is. Yet if virtue is not teachable, and hence acquiring virtue is not broadly under our control, this would undermine the argument in a different way. Becoming as good as possible would not be within our control and hence it could not be important for us to do it (contra the first premise). Hence, if Socrates thought that virtue were not teachable, he could not think that the argument at the end of the Laches provides us with good reason to search for knowledge of what it is. He might think that his interlocutors would be persuaded by the argument, but he would be presenting a purely dialectical argument, not one that provided reasons he took to be good. In the Protagoras Socrates says that he has never thought that virtue can be taught and so is doubtful that Protagoras could teach it (319a-b). Does this suggest, then, that Socrates' views in the Laches are incompatible with those in the Protagoras?

It is tempting to think that Socrates does not really doubt virtue's teachability in the Protagoras and the Meno. Perhaps this is correct and, if so, there is no incompatibility. But even if Socrates really is concerned that virtue cannot be taught, this need not pose a problem for his advice at the end of the Laches. He could simply be deeply conflicted about whether we can control the acquisition of virtue. On the one hand, he has no proof that it cannot be acquired and the possibility that it can offers a pathway to improving ourselves and our children. On the other hand, he has never met a real teacher of virtue, social institutions are set up on the assumption that it is not teachable, parents that seem to have virtue do not succeed in teaching it to their children, etc. If Socrates is conflicted, this explains his strong interest in whether virtue is teachable. Of course, the mere possibility that it is not teachable should not deter us from searching for what it is. While Socrates may have serious doubts about whether virtue is teachable, he does not know that it is not. This is why he tells us at the end of the Protagoras and the end of the Meno to hold off final judgment about teachability until we know what virtue is. The same holds for the Laches: we should keep open the possibility that we can acquire virtue unless we acquire knowledge that we cannot.

\section{Conclusion}

Socrates thinks that knowledge of what virtue is provides us with a valuable power: it helps us recognize what it would be to improve ourselves. This recognitional role is crucial; without it, there is in general no reason for Socrates' interlocutors to accept that they should seek such knowledge. Socrates' argument does not rely on substantive claims about virtue or the good. It only requires that

${ }^{33} \mathrm{I}$ argue for this position in greater detail in Ebrey 2013. 
we realize that we are ignorant. The argument not only helps us understand why Socrates' interlocutors should be motivated to seek knowledge of what virtue is, it also provides Socrates himself with one reason (among others) to search for this knowledge. Since he does not have the knowledge that would guide him to the good life, he thinks he should search for it. Given how confidently Socrates lives his life, it might seem that he must already think that he has such knowledge. The argument in the hortatory passage explains how he can be so confident without knowing how to live. He has reason to be confident about what he should do right now, search for knowledge of what virtue is, without being confident about what he will discover. ${ }^{34}$

Institute for Research in the Humanities

University of Wisconsin-Madison

Madison WI 53706

\section{BIBLIOGRAPHY}

Adkins, Arthur. 1960. Merit and Responsibility: A Study in Greek Values. Oxford: Clarendon Press. Benson, Hugh. 2000. Socratic Wisdom: The Model of Knowledge in Plato's Early Dialogues. Oxford: Oxford University Press.

Brickhouse, Thomas C. and Nicholas D. Smith. 1994. Plato's Socrates. Oxford: Oxford University Press.

Cooper, John and D.S. Hutchinson edd. 1997. Plato: Complete Works. Indianapolis: Hackett.

Dover, K.J. 1974. Greek Popular Morality In the time of Plato and Aristotle. Berkeley: University of California Press.

Ebrey, David. 2013. 'A New Philosophical Tool in the Meno: 86e-87c' Ancient Philosophy 33: 7596.

Ebrey, David. 2017. 'The Asceticism of the Phaedo: Pleasure, Purification, and the Soul's Proper Activity' Archiv für Geschichte der Philosophie 99: 1-30.

Forster, Michael. 2006. 'Socrates' Demand for Definitions' Oxford Studies in Ancient Philosophy 31: $1-48$.

Forster, Michael. 2007. 'Socrates' Profession of Ignorance' Oxford Studies in Ancient Philosophy 32: $1-36$.

Frede, Michael. 1992. Introduction to S. Lombardo and K. Bell trans. Plato's Protagoras. Indianapolis: Hackett.

Hagen, Daniel. 2013. Moral Expertise and Moral Education: A Socratic Account MIT PhD Dissertation.

Irwin, Terence. 1995. Plato's Ethics. Oxford: Oxford University Press.

Moss, Jessica. 2007. 'The Doctor and the Pastry Chef: Pleasure and Persuasion in Plato's Gorgias' Ancient Philosophy 27: 229-249.

Nehamas, Alexander. 1987. 'Socratic Intellectualism' Proceedings of the Boston Area Colloquium in Ancient Philosophy 2: 275-316.

Nehamas, Alexander. 1998. The Art of Living: Socratic Reflections from Plato to Foucault. Berkeley: University of California Press.

Penner, Terrence. 1992. 'What Laches and Nicias Miss-And Whether Socrates Thinks Courage Merely a Part of Virtue' Ancient Philosophy 12: 1-27.

34 This article has taken a long time coming to fruition. I have received generous help on earlier drafts from Andreas Anagnostopoulos, Rachel Barney, Hugh Benson, Eric Brown, Emily Fletcher, Rachana Kamtekar, Joe Karbowski, Sean Kelsey, Richard Kraut, Melissa Lane, Alison Mastny, Martha Nussbaum, Ron Polansky, Nick Smith, John Wynne, anonymous referees, Berkeley's working group in ancient philosophy, and Northwestern's junior faculty working group. 
Reeve, C.D.C. 1989. Socrates in the Apology. Indianapolis: Hackett.

Reshotko, Naomi. 2006. Socratic Virtue: Making the Best of the Neither-Good-Nor-Bad. Cambridge: Cambridge University Press.

Rudebusch, George. 2009. Socrates. Malden: Wiley-Blackwell.

Schofield, Malcolm. 2010. Plato: Gorgias, Menexenus, Protagoras. Tom Griffith trans. Cambridge: Cambridge University Press.

Scott, Dominic. 2006. Plato's Meno. Cambridge: Cambridge University Press.

Vlastos, Gregory. 1958. 'Paradox of Socrates' Queen's Quarterly 64: 496-516. Reprinted 1-21 in Vlastos ed. 1971. The Philosophy of Socrates: A Collection of Critical Essays. Garden City, NY: Anchor. 1971. (Page references are to the reprint).

Vlastos, Gregory. 1983. 'The Socratic Elenchus' Oxford Studies in Ancient Philosophy 1: 27-58.

Vlastos, Gregory. 1985. 'Socrates' Disavowal of Knowledge' Philosophical Quarterly 35: 1-31.

Vlastos, Gregory. 1991. Socrates: Ironist and Moral Philosopher. Ithaca: Cornell University Press.

Vasiliou, Iakovos. 2008. Aiming at Virtue in Plato. Cambridge: Cambridge University Press.

Wolfsdorf, David. 2004. 'Socrates' Avowals of Knowledge' Phronesis 49: 75-142.

Wolfsdorf, David. 2008. Trials of Reason: Plato and the Crafting of Philosophy. Oxford: Oxford University Press. 